\title{
The Vernacular Bible between Jews and Protestants
}

\section{Translation and Polemics in Early Modern Germany}

The longstanding Christian ambition to convert the Jews to Christianity received a new impetus with the Reformation and the beginning of the Protestant movement. Responding to Luther's call from the early 1520s regarding the need to deal kindly with the Jews and to instruct them carefully from the Holy Scriptures to encourage their conversion, ${ }^{1}$ Protestant theologians and missionaries in the German lands sought suitable methods for successful mission. After realizing that anti-Jewish polemics in Latin, German, or even Hebrew, proved useless among the wider segments of the German-Jewish population, they decided to address the Jews in the Jewish vernacular, that is, in Yiddish. During the Middle Ages and the early modern period, Yiddish served the Jewish communities in the German-speaking lands as the spoken language and, alongside Hebrew, also as a written language. Known today as 'Old' or 'Western' Yiddish (as opposed to Modern Yiddish, which evolved in Eastern Europe), the early modern German-Jewish vernacular was composed almost exclusively from German and Hebrew components, so that - at least from a linguistic perspective - it was much closer to German than modern Yiddish. ${ }^{2}$

The ambition of Protestant theologians and missionaries to use Yiddish as part of an assertive and competent mission among the Jews resulted in numerous missionary writings in the language, written and published in the German lands between the mid-sixteenth century and the second half of the eighteenth century. These included Yiddish translations of the Old and New Testaments (either in part or complete, and often after Luther's German Bible), the Catechisms, and various anti-Jewish (and pro-Christian) polemical writings. After initial pub-

1 Martin Luther, "Daß Jesus Christus ein geborner Jude sei" (1523), in D. Martin Luthers Werke, Kritische Gesamtausgabe. 120 vols. (Weimar: Böhlau, 1883-2009), vol. 11: 307-36 (henceforth: WA).

2 Modern Yiddish includes an additional Slavic component, absent from early modern Western Yiddish. On the history of Yiddish and the divide between Western and Eastern Yiddish see, in particular, Max Weinreich, History of the Yiddish Language, trans. Shlomo Noble, ed. Paul Glasser, 2 vols. (New Haven and London: Yale University Press, 2008) [originally published in Yiddish, New York: YIVO, 1973]. Throughout this paper, the term 'Yiddish' is used to designate Western Yiddish, the German-Jewish vernacular of the early modern period.

๑ OpenAccess. () 2020 Aue-Ben-David et al., published by De Gruyter. (cc) BY This work is licensed under the Creative Commons Attribution 4.0 International. https://doi.org/10.1515/9783110664713-008 
lications of this kind during the latter half of the sixteenth century, ${ }^{3}$ the publication of missionary tracts in Yiddish reached its high point in the first decades of the eighteenth century, with the rise of the Pietist movement within Lutheranism and its renewed emphasis on Jewish conversion. In 1728, the devoted pietist and professor of philosophy and oriental languages at the University of Halle, Johann Heinrich Callenberg (1694-1760), established in the city the Institutum Judaicum et Muhammedicum, with the outright aim of spreading Christianity among Jews and Muslims. In addition to the training of professional missionaries, the Institute also had its own printing shop, dedicated to the publication and distribution of missionary writings; first and foremost, in the German-Jewish vernacular. ${ }^{4}$

The missionary initiative of translating the New Testament and other Christian works into Yiddish in order to make them accessible to a Jewish readership seems perfectly reasonable. Less clear, however, are the attempts of Protestant missionaries to translate the Old Testament (i.e. the Hebrew Bible) into Yiddish for the benefit of Jewish readers. After all, the Jews had not exactly been waiting for the Christians to produce for them Yiddish translations of the Bible. At least from the fifteenth century, Ashkenazi Jews had in their possession Yiddish versions of biblical books: first in the form of manuscripts, and, since the mid-sixteenth century, also in print. ${ }^{5}$

3 Most notably, the Yiddish Pentateuch (with Haftarot and Megillot) of the Protestant Reformer Paulus Fagius and the Yiddish versions of the New Testament published by the convert Paul Helic (c. 1500 - c. 1560) and the Protestant theologian Elias Schadeus (c. 1541-1593). See: Paulus Fagius, ed., and [Michael Adam (?)], trans., Hamishah Humshei Torah im Hamesh Megillot vehaHaftarot / Die fünff bücher Mosis sampt dem Hohen lied Salomonis ... (Constance: Fagius, 1544) (this translation appeared in two different editions: one with a Yiddish title and introduction, addressed to the Jewish reader, and one with a German title and introduction, addressed to the Christian reader); Paul Helic, ed., and [Johann Harzuge (?)], trans., Das noyay Testyment das da wert ginent Evani[g]elyun ... das ist ... Besurah Toyveh (Cracow: Helic, 1540); Elias Schadeus, ed. and trans, Fünff Bücher des Newen Testaments (Strasbourg: Schadeus, 1592).

4 On the missionary activity of the Institute, see, especially, Christoph Rymatzki, Hallischer Pietismus und Judenmission: Johann Heinrich Callenbergs Institutum Judaicum und dessen Freundeskreis (1728-1736) (Tübingen: Niemeyer, 2004); Christopher Clark, The Politics of Conversion: Missionary Protestantism and the Jews in Prussia 1728-1941 (Oxford: Clarendon Press, 1995), Ch. 2. For an elaborated discussion and analysis of the Institute activities in Yiddish, see Aya Elyada, "Yiddish - Language of Conversion? Linguistic Adaptation and Its Limits in Early Modern Judenmission,” Leo Baeck Institute Year Book 53 (2008): 3-29, and eadem, A Goy Who Speaks Yiddish: Christians and the Jewish Language in Early Modern Germany (Stanford, CA: Stanford University Press, 2012), Ch. 1.

5 On pre-modern Yiddish biblical translations, see, especially, Chone Shmeruk, Sifrut Yidish Prakim le’Toldoteha (Tel Aviv: Tel Aviv University, 1978), Ch. 4, and Jean Baumgarten, Introduction to Old Yiddish Literature, ed. and trans. Jerold C. Frakes (Oxford and New York: Oxford Uni- 
The literary tradition of translating biblical texts from Hebrew into Yiddish, culminating in the publication of two complete Yiddish bibles in Amsterdam in the late seventeenth century, ${ }^{6}$ originated from the traditional study of the Bible in the Ashkenazi kheyder, the religious primary school for Jewish boys. Since Hebrew was no longer the children's mother tongue, the Bible lessons in the kheyder were mainly comprised of the oral translation of each successive word from Hebrew into Yiddish. The melamed, or teacher, recited with the children every Hebrew word of the text, followed by its Yiddish equivalent. From the Middle Ages onwards, an entire corpus of supporting literature developed to assist in this form of Bible study. In the first stage, Yiddish glosses were added to Hebrew manuscripts, intended to clarify difficult terms in the biblical text and the commentaries. In the course of the sixteenth century, this medieval tradition further developed with the publication of printed glossaries, concordances, and biblical lexicons. ${ }^{7}$

The gloss tradition also gave rise to the so-called taytsh-khumesh, a literal translation of the Bible in which every word or phrase in the Hebrew original is replaced with a corresponding Yiddish one. These verbatim translations were intended for use not only in the kheyder, but also in the synagogue, as a

versity Press, 2005), Ch. 5, with further references. See also Chava Turniansky, "Reception and Rejection of Yiddish Renderings of the Bible," in The Bible in/and Yiddish, ed. Shlomo Berger (Amsterdam: Menasseh ben Israel Institute, 2007): 7-20.

6 Yekuti'el b. Yitzhak Blitz, trans., Hamisha humshe tora nevi'im u-ketuvim bi-leshon ashkenaz ... (Amsterdam: Uri Phoebus, 1678) and Yosef bar Alexander Witzenhausen, trans., Tora nevi'im u-ketuvim mi-leshon ha-kodesh ... (Amsterdam: Yosef Athias, 1679) ( $2^{\text {nd }}$ ed. 1687). On these Yiddish bibles, see, especially, Marion Aptroot, "'In galkhes they do not say so, but the taytsh is as it stands here': Notes on the Amsterdam Yiddish Bible translations by Blitz and Witzenhausen," Studia Rosenthaliana 27 (1993): 136-58, and eadem, "Yiddish Bibles in Amsterdam," in Berger, ed., Bible in/and Yiddish, 42-60.

7 Here one should mention Mirkeves ha-mishne of Rabbi Anshel, a Hebrew-Yiddish biblical concordance published in Cracow in 1534, which is the first-known Yiddish printed book, and the two biblical dictionaries from the beginning of the seventeenth century: Moses ben Issachar Sertels, Seyfer beeyr Moushe (Prague: Moses ben Bezalel, 1604-5), which includes terms from the Pentateuch, and idem, Seyfer lekakh tov (Prague: Moses ben Bezalel, 1604), which includes terms from the Prophets and Hagiographa. See Baumgarten, Old Yiddish Literature, 22-3. For an elaborate discussion on the teaching method in the kheyder and its close relations to the Yiddish lexicographical tradition see Chava Turniansky, "Halimud baheder ba'et ha'hadasha hamukdemet," in Haheder: mehkarim, te'udot, pirkey sifrut vezihronot, eds. Emanuel Etkes and David Assaf (Tel Aviv: Tel Aviv University, 2010), 3-35, esp. 22ff.; and see also Walter Röll, "Die Bibelübersetzung ins Jiddische im 14. und 15. Jahrhundert," in Die Vermittlung geistlicher Inhalte im deutschen Mittelalter, eds. Timothy R. Jackson, Nigel F. Palmer, and Almut Suerbaum (Tübingen: Niemeyer, 1996), 183-95. 
means for achieving a better understanding of the Hebrew text, and in the Jewish home, as reading material for the women and uneducated men. ${ }^{8}$

Protestant scholars, especially theologians, Hebraists, and Orientalists, were well acquainted with the Yiddish biblical translations that circulated in the Jewish communities. Bibliographical works of prominent theologians in which Jewish literature or different versions of the Old Testament are discussed often feature information on Yiddish bibles, sometimes even entire reviews. ${ }^{9}$ Missionaries also read the Yiddish biblical translations - together with other Yiddish works that were popular among the Jews at the time, such as the Tsene-rene and the Mayse-bukh - mining them for information about contemporary Jewish beliefs (the famous 'know your enemy' stratagem). The idea, of course, was that familiarity with popular Yiddish literature, including biblical translations and adaptations, would achieve a more effective mission. ${ }^{10}$ Perhaps more surprisingly, Protestant theologians and Hebraists even used such Yiddish translations, originally prepared by Jewish authors for the Jewish reading public, for intra-Chris-

8 On the taytsh-khumesh tradition, see, especially, Chava Turniansky, "Letoldot ha-'taytsh-khumesh': 'khumesh mit khibur'," in Iyunim besifrut: dvarim shene'emru be'erev likhvod Dov Sadan bimlot lo shmonim ve'khamesh shana, ed. Chone Shmeruk (Jerusalem: Israel National Science Academy, 1988), 21-51; eadem, "Halimud baheder," esp. 22ff.; eadem, "Reception and Rejection”; Erika Timm, Historische jiddische Semantik: Bibelübersetzungssprache als Faktor der Auseinanderentwicklung des jiddischen und des deutschen Wortschatzes (Tübingen: Niemeyer, 2005); and Baumgarten, Old Yiddish Literature, Ch. 5.

9 See, e.g., Christian Kortholt, De variis scripturae editionibus tractatus theologico-historicophilologicus (Kiel: Richelius, 1686); Jacob Le Long, Bibliothecae sacrae pars altera (Leipzig: Gleditsch and Weidmann, 1709); Johann Christoph Wolf, Bibliotheca Hebraea, 4 vols. (Hamburg and Leipzig: Liebezeit, 1715-33), here: vol. II, 1721; Johann Gottlob Carpzov, Critica Sacra Veteris Testamenti (Leipzig: Martin, 1728); Wilhelm Christian Just Chrysander, Unterricht vom Nutzen des Juden-Teutschen (Wolfenbüttel: Meißner, 1750).

10 As the ardent advocate of Jewish mission in Yiddish, Wilhelm Christian Just Chrysander (1718-1788), noted, reading Yiddish literature would be beneficial for Christians in that "one makes for oneself, from their own books, a more accurate and complete notion of the condition of present-day Jews, [...] their teachings, [...] customs, prevalent prejudices, motivations, most common/base sins, blasphemies [...] etc. Consequently, one would be more skilled to missionize them [...] and would be able to better choose the most convenient means for winning them over" (Chrysander, Unterricht vom Nutzen, 20; unless mentioned otherwise, all translations throughout the paper are my own). With regard to specific Yiddish works see, for instance, ibid., 7-8; Christoph Helvicus, ed. and trans., Jüdischer Historien oder Thalmuhdischer / Rabbinischer / wunderbarlicher Legenden .... 2 vols. (Gießen: Chemlein, 1612), vol. 1, intro., n.p.; vol. 2, intro., n.p.; Johann Christoph Wagenseil, "Rabbi Mose Stendels nach Jüdisch-Teutscher RedArt vorlängst in Reimen gebrachte Psalmen Davids," in idem, Benachrichtigungen wegen einiger die Judenschafft angehenden wichtigen Sachen (Leipzig: Heinichen, 1705), n.p. (here: intro., n.p.). 
tian purposes; specifically, as a means of assistance, or Hilfsmittel, for achieving an accurate reading and understanding of the Hebrew Bible. In some cases, where nothing better could be found, the Yiddish translations were even used by Christians as substitutes for Hebrew dictionaries and lexicons. ${ }^{11}$

So far, we have seen that the Jews of the Holy Roman Empire enjoyed a long and substantial tradition of Yiddish biblical translations and that contemporary Christian theologians and missionaries were well aware of this tradition. So why did the latter consider it necessary to produce additional Yiddish translations of biblical texts for distribution among the Jews? One possible answer is that the Christian missionaries were aware of the fact that the plain Yiddish biblical translations (according to the pshat) were not particularly popular among the Jews, especially in comparison to other genres of biblical literature in the Jewish vernacular, such as the Tsene-rene, which contained large portions of aggadot and midrashim. ${ }^{12}$ Hence, in the spirit of sola scriptura, they wished to enhance the dissemination of plain versions of the Bible in Yiddish among the Jews. Another possibility, which stands at the focus of this essay, is that the Protestant theologians and missionaries were simply not content with the existing Yiddish versions of the Bible, prepared for the Jews by Jewish translators. In their eyes, the Jewish Yiddish bibles were inadequate as media for the transmission of religious truth: instead of serving the Jews as a means to draw nearer to the Word of God, these translations were perceived as preventing the Jews from comprehending and accepting the divine message.

11 Thus, for example, the influential theologian and Hebraist Johann Christoph Wagenseil explained that, whenever he encounters an obscure passage in the Hebrew Bible, he examines biblical translations and interpretations in Yiddish and other languages, such as Aramaic, Greek and Latin, so as to achieve an accurate literal understanding of the text. But, he notes, it is usually the case "that the Jewish-German [i.e. Yiddish] translation of the words and interpretation of a saying is more beneficial for me than all remaining aids, and that I remain with this [translation]: how it then gives word for word, as clear as it can only be, regardless whether it sounds well or foul in the German language"; Johann Christoph Wagenseil, Belehrung der Jüdisch-Teutschen Red- und Schreibart (Königsberg: Rhode, 1699), intro., n.p. And see also idem, "Rabbi Mose Stendels," intro., n.p.; Johann Buxtorf, Thesaurus grammaticus linguae sanctae hebraeae (Basel: Waldkirch, 1609), 652; Chrysander, Unterricht vom Nutzen, 6, 19; and the editor's introduction to the Biblia Pentapla, Das ist: Die Bücher der Heiligen Schrift ..., Nach Fünf-facher Deutscher Verdolmetschung, 3 vols. (Wandsbeck and Schiffbeck: Holle, 1710-12), vol. 1, intro., n.p.; vol. 2, intro., n.p.

12 On the popularity of the various genres of biblical literature in Yiddish see, e.g., Turniansky, "Reception and Rejection"; see also Baumgarten, Old Yiddish Literature, Ch. 5. 


\section{Protestant Criticism of Jewish Biblical Translations}

What was it, then, in the Yiddish biblical translations, that aroused the ire of the Protestant scholars? A central motif in the Christian criticism was the Jewish practice of translating biblical works from Hebrew into Yiddish in a strictly wordfor-word manner. Emerging from a point of deep respect for the sanctity of the biblical text, the Yiddish bibles aimed to keep the translation as close as possible to the literal meaning of the Hebrew original, leaving aside the syntactic and lexical rules of spoken Yiddish, which were closer to German. For Christian scholars, the Jewish custom of translating verbatim from Hebrew into Yiddish, "unangesehen wie übel es im deutschen lautet" (regardless of how bad it sounds in German), rendered the Yiddish translations of the Bible stylistically inferior and barely intelligible. ${ }^{13}$ Moreover, this method of translation was commonly seen as indicative of 'Jewish superstition.' These severe condemnations appear clearly in the words of Johannes Buxtorf (1564-1629), the most influential Christian Hebraist and Yiddishist of the seventeenth century. Discussing the Jewish custom of translating from Hebrew into Yiddish, Buxtorf opined that

this is, however, a flaw common to them [the Jews] all: that what they translate from Hebrew, they translate too literally. The Hebraisms are so persistent that they obscure the German idiom. They superstitiously (superstitiose) hold so closely to preserving the extraneous and literal word that they sometimes leave no sense at all; sometimes the sense is obscure, sometimes disagreeable. The more ignorant a person is, the more superstitious he is in this regard..$^{14}$

One frequently finds such disparagement of verbatim translation (verbum pro verbo) as 'superstitious' and inferior to translating the sense of a given text (sensum de sensu) in early modern discussions on the art of translation. ${ }^{15}$ In the Jewish context, however, this notion also alluded to an enduring motif in Christian anti-Jewish polemics regarding the Jews' 'superstitious' adherence to the literal meaning of the biblical text at the expense of a deeper and more spiritual understanding. The claim that the Jews were captives of the letter of the Bible and disregarded its spirit goes back to the Church fathers, but it became especially evi-

13 Quote from Fagius, ed., Die fünff bücher Mosis, intro., n.p. On this point see also below.

14 Buxtorf, Thesaurus grammaticus, 652.

15 See Peter Burke, "Cultures of Translation in Early Modern Europe," in Cultural Translation in Early Modern Europe, eds. Peter Burke and R. Po-chia Hsia (Cambridge: Cambridge University Press, 2007), 7-38, here at $24 \mathrm{ff}$. 
dent in Protestant circles. As an unshakeable expression of the Jews' literalmindedness, the Jewish practice of translating the Bible in a word-for-word manner was presented in sharp contrast to the 'spiritual' interpretation of the Bible in Christian, mainly Protestant, tradition.

But Jewish superstition and 'servitude of the letter' (Buchstabendienst) accounted only partially, according to the Protestant authors, for the literal translation of the Bible into Yiddish. A second reason, from their perspective, was that the Jews were simply not capable of producing better translations. Since the Jews read the Bible according to rabbinic interpretations, so ran the argument, they cannot truly understand the text, let alone correctly translate it. As Jewish versions of the holy text, the Yiddish biblical translations were, as one eighteenth-century Protestant scholar formulated it, "noch mit der Decke Mosis beleget" (still covered with Moses' veil), and therefore surely false and mistaken. ${ }^{16}$ In this regard, some authors quote from Martin Luther's Sendbrief vom Dolmetschen (An Open Letter on Translating, 1530), in which Luther criticizes a German translation of the Prophets that was published in Worms in 1527. About this translation, which was prepared by Christians with the assistance of Jewish scholars, Luther writes:

the art of translation is not a simple craft like any other [...]; It calls for a righteous, pious, true, hard-working, God-fearing, Christian [...] heart. For that reason, I believe that no false Christian or divisive spirit (rottengeist) can translate faithfully, as is clear from the Prophets that were translated into German and published in Worms. There is no doubt that much effort was put in it, and it closely follows my own German; but there were Jews involved, who did not show much respect for Christ; apart from that, it shows sufficient skill and hard work. ${ }^{17}$

Closely related to the idea that the Jews, by virtue of being Jews, were unable to correctly translate the Bible, was the claim of many Protestant Hebraists and Yiddishists that the Jews could not translate in a correct manner because they had lost their mastery of the Hebrew language. "The Jews of our time are ignorant of the Hebrew tongue," lamented the famous Hebraist Johann Christoph Wagenseil $(1633-1705)$ in 1705 ,

and because of that, among other things, the veil hangs in front of their eyes, which prevents them from truly understanding the writings of Moses and the prophets; and so,

16 See the editor's introduction to the Biblia Pentapla, vol. 1, intro., n.p.; and vol. 2, intro., n.p. 17 Martin Luther, "Sendbrief vom Dolmetschen” (1530), in WA 30 (2), 632-46, here at 640. This quote appears, for example, in Kortholt, De variis scripturae, 341-2; and Wolf, Bibliotheca Hebraea, vol. II, 455-6. 
among many hundreds of Jews, not a single one can be found, who can clearly explain even one chapter of the [Five Books of] Moses, not to mention from the Psalms, Job, or the Prophets, and render it in a comprehensible and correct manner. ${ }^{18}$

This association between the Jews' lack of proficiency in Hebrew and their insufficient knowledge of the Bible already appeared in the writings of the sixteenthcentury reformer Paulus Fagius (1504-1549), who interpreted both disadvantages as God's punishment of the Jewish people: "They are called the Hebrews (Hebreer), and yet there is no other people under the sun that has less understanding of the true, proper Hebrew language." And he adds: "And so we can see how dreadfully the Lord has punished and afflicted them, in that he took from them not only the correct and true understanding of the Holy Scripture, but also the means by which they could have attained such understanding."19

Even worse than the Jewish practice of translating word-for-word from Hebrew into Yiddish were the passages in the Yiddish biblical translations that, from a Christian perspective, deviated from the literal meaning of the Hebrew source text. According to the Protestant authors, the Jews aimed in this way to deliberately falsify and pervert the Hebrew text, and especially the optima de Messia oracula, or the places that bear witness to the expected coming of Christ. Moreover, the Jewish translators were accused of shamelessly integrating extensive passages of Jewish apologetics and anti-Christian polemic in the Yiddish texts, "by which the reader is led away from the beneficial use of the divine Word (a salutari verbi coelestis usu),"20 and especially from the acknowledgment of Christ.

18 Johann Christoph Wagenseil, "Die Hoffnung der Erlösung Israelis,” in idem, Benachrichtigungen, 1-125, here at 41.

19 Fagius, Die fünff bücher Mosis, intro., n.p. Similar statements regarding the loss of Hebrew among the German Jews appear in the writings of Protestant Hebraists and Yiddishists throughout the early modern period. See, for example, Sebastian Münster, Chaldaica grammatica (Basel: Froben, 1527), 4; Johann Jacob Schudt, Jüdische Merckwürdigkeiten, 4 vols. (Frankfurt a.M. and Leipzig: Hocker, 1714-18), here vol. 2, 281-2; Wagenseil, “Rabbi Mose Stendels,” intro., n.p.; Johann Christoph Bodenschatz, Kirchliche Verfassung der heutigen Juden sonderlich derer in Deutschland (Frankfurt and Leipzig: Selbstverl., 1749), pt 4, 94; Johann Heinrich Callenberg, Neue summarische Nachricht von einem Versuch, das arme jüdische Volck zur Erkäntniss und Annehmung der christlichen Wahrheit anzuleiten (Halle: Buchdruckerey des jüdischen Instituti, 1735), 65-6; and idem, Bericht an einige Christliche Freunde von einem Versuch, das arme Jüdische Volck zur Erkäntniß und Annehmung der Christlichen Wahrheit anzuleiten (Halle: Krottendorff, 1730), esp. Dreyzehnte Fortsetzung (1735), 36, 54-5.

20 Quote from Johann Heinrich Callenberg, ed. and trans., Genesis germanice litteris judaicogermanicis (Halle: Institutum Judaicum, 1737), intro., n.p. 
Accusations of anti-Christian propaganda were often levelled at the first complete Yiddish version of the Bible, translated by Jekuthiel ben Isaac Blitz (c. 1634-1684) and published in Amsterdam in 1678. The Lutheran theologian and Hebraist from Frankfurt am Main, Johann Jacob Schudt (1664-1722), was one such indicter. In his extensive ethnographic work, Jüdische Merckwürdigkeiten (Jewish curiosities) from the year 1714, Schudt related to this "foolish, tasteless, vicious Jewish-German translation of the Old Testament" (alber[n]e / $a b$ geschmackte / boßhafftige Juden-Teutsche Übersetzung des Alten Testaments) as part of his discussion of Jewish life in Holland. Vehemently attacking Amsterdam's authorities for the lack of adequate censorship in their city, Schudt considered this Yiddish bible decisive proof of the unwelcome results of the overly extensive freedom enjoyed by the Jews in Holland, as he formulates it, where "the Jews have their own printing shops, and there they may freely publish their blasphemous books at their liking [...], in which they blaspheme and disgrace Jesus and our faith.” As an example of the way the Jewish translator allegedly falsified and misinterpreted "the clearest prophecies of the Lord Messiah" (die klahreste Weissagungen vom Herrn Messia), Schudt cites Blitz's translation of Isaiah 7:14, a central point of controversy between Jews and Christians over the centuries. Relating to the second part of the verse, "hine ha'alma hara ve-yoledet ben" (The virgin will be with child and will give birth to a son), Schudt sharply criticizes Blitz for translating the word alma not as a Jungfrau (virgin), but rather as a junge Frau (ינגי פרויא'; young woman), thus deliberately pulling the rug out from under a fundamental Christian tenet. ${ }^{21}$

According to this and many other examples, ${ }^{22}$ the 'problematic' places in Yiddish bibles were not simply viewed as the outcome of some translation fallacy, and certainly not as a legitimate alternative to their own interpretation, but as a strategic mistranslation, ideologically motivated by anti-Christian impulses. The old Italian adage, traduttore, traditore (a translator is a traitor), is thus imbued in this case with additional meanings, taken not from the world of literary criticism but from that of Christian-Jewish polemics. The Jews, on this view, used

21 Schudt, Jüdische Merckwürdigkeiten, vol. 1, 284-5. For more attacks on Blitz's Yiddish bible, see, for example, Kortholt, De variis scripturae, 343-4; Carpzov, Critica Sacra, 759-78; Chrysander, Unterricht vom Nutzen, 7-9; Anon., Nachrichten von einer Hallischen Bibliothek, vol. 3 (Halle: Gebauer, 1749), 106-8.

22 For denunciations of Jewish 'blasphemies' and anti-Christian expressions in other Yiddish prayer books and biblical translations see Kortholt, De variis scripturae, 342; Carpzov, Critica Sacra, 753-6; Wagenseil, "Rabbi Mose Stendels," intro., n.p.; Chrysander, Unterricht vom Nutzen, 14. 
the medium of translation to manipulate the holy text and hence as a weapon in the war they waged against Christian tenets in their Jewish vernacular.

\section{Protestant Criticism of the German-Jewish Vernacular}

The Christian charges discussed thus far, namely, that the Jews were incapable of fathoming the Bible correctly, that they translated the holy text too literally, and that they falsified biblical verses in order to conceal the places referring to Christ were, of course, ancient in origin. Rooted in the teachings of the Church Fathers, they constituted central motifs in anti-Jewish polemics during the Middle Ages and the early modern period, where they also came forward in Christian, mainly Protestant, discussions on the Yiddish Bible. Other points of critique, however, were directed specifically at the Yiddish biblical translations, or, more precisely, at the language and style of these texts.

As far as the Christian authors were concerned, Yiddish was basically a kind of German. Thus, in their eyes, the Yiddish biblical translations were in fact German translations. The other characteristics of Yiddish - most notably that Yiddish had a considerable Hebraic component, that many of the German words were pronounced differently, and that the Jews also used 'peculiar words' (sonderliche Wörter), namely, words from other languages as well as older German words - were usually perceived by the Christian authors as mere deviations from or, indeed, a corruption of their own German language. ${ }^{23}$

The prevailing assumption among Christian scholars, that Yiddish was no more than "incorrect, corrupted, unreadable, and incomprehensible German" (ein gantz falsches / corruptes / unleserliches unverständliches Teutsch), ${ }^{24}$ influenced their perceptions of the Yiddish biblical translations. Thus, for instance, we read in the works of early modern Protestant theologians like Christian Kortholt (1633-1694) and Johann Gottlob Carpzov (1679-1767) that the Yiddish bibles of the Jews, "[have] an unrefined and barbaric style, [...] highly unsatisfactory for either Christian or for German ears.”25 Depreciations of this kind appear

23 For an elaborate discussion on this point see Aya Elyada, “Eigentlich Teutsch'? Depictions of Yiddish and Its Relations to German in Early Modern Christian Writings," European Journal of Jewish Studies 4 (2010): 23-42, and eadem, A Goy Who Speaks Yiddish, Ch 7.

24 Quote from Caspar Calvör, Gloria Christi, oder Herrligkeit Jesu Christi (Leipzig: Göze, 1710), intro., n.p.

25 Carpzov, Critica Sacra, 751-3 (quote from 751), referring to the translation of Witzenhausen (1679); on p. 759 he directs the same criticism towards the translation of Blitz (1678). 
in later works as well. In 1784, the professor of theology in Altdorf and Jena, Johann Christoph Doederlein (1745-1792), criticized the language of Yiddish biblical translations in earlier periods, denouncing it as "utterly impure, barbaric, [...] often ridiculous, and conducive to the maintenance of the language-barbarism (Sprachbarbarey) among the Jews."26

More egregious than the aesthetical problem was, from the vantage point of the Protestant authors, the problem of understanding, or rather misunderstanding, caused by the corrupted Yiddish language. The Lutheran theologian and Superintendant Caspar Calvör (1650 - 1725), for example, argued at the beginning of the eighteenth century that since Yiddish has no proper grammar or accurate orthography, readers of Yiddish works, even the German Jews themselves, are unable to reach a true understanding of such texts. ${ }^{27}$ The assertion that the Yiddish bibles were incomprehensible even to Yiddish-speaking Jews had, of course, serious theological implications: if the language of these bibles blocked the transmission of the holy truth, how would the Jews ever acquire it?

The Christian notion that the adulterated language of the Yiddish bibles yielded texts that lacked both clarity and purity was reinforced by the aforementioned Jewish practice of translating the Bible in a word-for-word manner. Since this translation method further contributed to the deviation of the language of translation (the so-called khumesh-taytsh) from the syntactic structure of German, it was viewed as largely responsible for the fact that, "when one reads or hears it, one might think it is gibberish rather than German" (billicher Kauderwelsch als Teutsch). ${ }^{28}$ Jewish translators, argued the theologians,

regard the character and true essence of the German language as completely unimportant, corrupting and falsifying it, that it is sometimes difficult to understand the meaning of the text [...] sometimes they cling so firmly to the Hebrew letters, so that it becomes completely unintelligible in German. ${ }^{29}$

At this point, it is interesting to note that translating according to the sense of the text and into idiomatic German, in order to make Scripture as clear and comprehensible as possible to the broader population of German speakers, was a hall-

26 Johann Christoph Doederlein, Theologische Bibliothek, vol. 3 (Leipzig: Breitkopf, 1784), pt $1,3$.

27 Calvör, Gloria Christi, intro., n.p.

28 Fagius, Die fünff bücher Mosis, intro., n.p.; for similar notions see also Wagenseil, Belehrung der Jüdisch-Teutschen, intro., n.p. In 1705 Wagenseil referred to Mose Stendel's Yiddish translation of the psalms as a work that, "to tell the truth, should be called gibberish rather than German”; idem, "Rabbi Mose Stendels," intro., n.p.

29 Quote from Carpzov, Critica Sacra, 752-3, who also provides lengthy examples. 
mark of Luther's own vernacular Bible. This characteristic clearly distinguished his translation from Catholic, pre-Reformation German versions of the Bible. These pre-Reformation German bibles were, in fact, translations of the Latin Vulgate, and followed the Latin text in a verbatim fashion, adapting the German language of translation to the Latin source. In his own translation of the Bible, Luther not only attempts to 'purge' the holy text from Catholic interpretations and theological influences; he also rejects wholesale the accepted method of translation, famously asserting that "one does not have to ask the literal Latin how one is to speak German.” Instead, Luther advocates an idiomatic, even colloquial translation, explaining that "I wanted to speak German, not Latin or Greek, since it was German I had undertaken to speak in the translation."30

In their criticism of the Jewish biblical texts in Yiddish, then, it seems that the Protestant authors followed Luther's approach regarding the desirable style and method for biblical translation. Yet the shifting of the discussion from the context of Protestant-Catholic polemics to that of a Protestant-Jewish one brought to the foreground a new factor: the complete and utter rejection of Yiddish, the Jewish vernacular, by the Protestant scholars and missionaries, as discussed above. Thus, in their own Yiddish biblical translations, such as those produced in the Pietist institute in Halle during the eighteenth century, Protestant missionaries were not satisfied with merely modifying the method of translation. Rather, they also attempted to 'improve' the Yiddish language by Germanizing it, that is, by reducing the Hebraic component of Yiddish to a minimum, or even eliminating it altogether, while retaining solely the Germanic component of the Jewish language. The outcome was that some 'Yiddish' biblical translations, as well as other missionary works, were in fact written in German with Hebrew letters, or in a highly 'Germanized' version of Yiddish. Whether this was the most appropriate medium for missionizing among the Jews is, of course, open to debate. ${ }^{31}$

30 See Luther, "Sendbrief vom Dolmetschen” (1530), quotes from WA 30 (2), 637. On Luther's translation of the Bible see, for example, Stephan Füssel, "Introduction," in The Bible in Pictures: Illustrations from the Workshop of Lucas Cranach (1534) (Cologne: Taschen, 2009), 4-32; Mark U. Edwards, Printing, Propaganda and Martin Luther (Berkeley, CA: University of California Press, 1994), Ch. 5; Eric W. Gritsch, "Luther as Bible Translator," in The Cambridge Companion to Martin Luther, ed. Donald K. McKim (Cambridge: Cambridge University Press, 2003), 62-72.

31 On this point see, especially, Elyada, "Yiddish - Language of Conversion?”; eadem, A Goy Who Speaks Yiddish, Ch. 8. 


\section{Conclusion: The Vernacular Bible Between Jews and Protestants}

The vernacular Bible was arguably one of the greatest achievements of the Protestant Reformation, and a major force behind its success. Luther's teachings of sola scriptura and the 'priesthood of all believers,' as formulated in his early writings, inevitably led to the Protestant assertion that the Holy Scripture should be made accessible to every man and woman, who would be able to read and understand the holy text in his or her native tongue. It is no surprise, therefore, that translating the Bible into German was one of the first and most important tasks of Luther as a reformer. Thus, while the Latin Vulgate remained - at least officially - the ultimate Bible of the Catholic Church, the vernacular Bible became the staple of the Protestant movements, resulting in the rapid translation of the holy book into the various European vernaculars from the sixteenth century onwards.

Within the Jewish-Ashkenazi world, vernacular - that is, Yiddish - translations of the Hebrew Bible existed already before the Protestant Reformation. These Jewish, Yiddish translations shared an important characteristic with Luther's and the other Protestant vernacular bibles: they, too, were meant to make the Bible accessible to the broader population, beyond the narrow religious and intellectual elite. In other respects, however, the early modern Yiddish translations of the Hebrew Bible resembled the Catholic, pre-Lutheran German translations of the Latin Vulgate: they produced a verbatim translation of the text, following closely the grammatical rules of the source language, at the expense of an idiomatic translation. Moreover, unlike the Protestant vernacular bibles, which were meant to replace the Vulgate as the canonical text, neither the Catholic nor the Jewish vernacular translations were intended to present an alternative to the hegemonic, sacred text - either in Hebrew or in Latin. Instead, they were seen mainly as inferior substitutes, auxiliary tools to better understand the one and only canonized text.

As this essay aimed to show, Protestant Hebraists and theologians disparaged the Jewish vernacular bibles precisely because of these 'Catholic' characteristics, in addition to their antagonism towards the Jewish religion and the Yiddish language and culture of their Jewish neighbors. Loyal to the Protestant teaching that an individual reading and understanding of the Bible is indispensable for gaining access to religious truth, they sought to provide contemporary Ashkenazi Jews with 'improved' texts of the Holy Scriptures: texts in which rabbinic interpretations were replaced by Christian ones and in which the Yiddish 
language underwent a process of Germanization; a true 'kosher' Christian Bible - in language, style, and content.

\section{Epilogue: Yiddish Bibles, Protestant Criticism, and the German-Jewish Haskalah}

The early modern Protestant mission to the Jews failed to achieve its goal. Despite the diligent publication and distribution of Yiddish missionary writings, including new, Protestant versions of Yiddish biblical texts, the Jews did not convert en masse to Christianity. Yet it seems that the Protestant theologians' and missionaries' critique of the Jewish vernacular Bible, and their attempts to 'improve' it, did have a certain impact - if not a religious or theological one, then at least in the linguistic and cultural domain.

In 1783, Moses Mendelssohn (1729-1786), the leading figure of the GermanJewish Haskalah (Jewish Enlightenment), published his own translation of the Pentateuch under the title Sefer Netivot Hashalom. ${ }^{32}$ As was the case with earlier Yiddish translations, Mendelssohn, too, designated his translation language as leshon Ashkenaz. By this, however, Mendelssohn did not mean the Yiddish language of his predecessors, but indeed a pure, clear Hochdeutsch, transliterated with Hebrew characters. ${ }^{33}$

In the introduction to his Pentateuch, Or Lintivah, Mendelssohn criticized earlier Yiddish translations of the Bible, such as the two seventeenth-century Amsterdam bibles of Yekutiel Blitz and Josel (Joseph) Witzenhausen (c. 1616-c. 1686), both for their method of verbatim translation which Mendelssohn vehemently rejected, and for the 'bad German' in which they were written. Referring to Blitz, for example, Mendelssohn claimed:

Even if his intention was good [...] his actions are not welcome at all, for he did not know the nature of the holy language, nor the depth of its idiom. What he garnered from it, he translated into a stammering, distorted and corrupt language, loathsome to the soul of

32 Moses Mendelssohn, Sefer netivot hashalom: ve-hu hibur kolel hameshet humshei ha-tora im tikun sofrim ve-targum Ashkenazi u-be’ur (Berlin: Starcke, 1783).

33 On Mendelssohn's Bible translation see, e.g., Werner Weinberg, "Language Questions Relating to Moses Mendelssohn's Pentateuch Translation,” Hebrew Union College Annual 55 (1984): 197-242; Nils Römer, Tradition und Akkulturation: Zum Sprachwandel der Juden in Deutschland zur Zeit der Haskalah (Münster and New York: Waxmann, 1995), Ch. 8; and, recently, Abigail Gillman, A History of German Jewish Bible Translation (Chicago, IL: University of Chicago Press, 2017), pt 1. 
the reader who knows how to speak [German] correctly (תגעל בה נפש הקורא היודע לדבר צחות). And since from then until now nobody has endeavoured to straighten the crooked and to translate the holy Torah into the refined language [i.e. German], the way it is spoken in our generation, [...] I took it upon myself to translate the Five Books of the Torah into decorous and refined German (בלשון אשכנז המסולסל והמתוקן), such as that spoken in our time, [...] sometimes after the word and sometimes after the sense, to educate [the children] in the correctness of the text and in the idiom of the tongue. ${ }^{34}$

This sort of assessment of the traditional Yiddish translations of the Bible and other religious texts was quite common among the German-Jewish maskilim, who attempted to provide the Jewish community with 'decent' (i.e. maskilic) substitutes in pure Hochdeutsch. ${ }^{35}$

What motivated Mendelssohn and his followers to offer the Jews pure German biblical translations has been debated intensively in historical research over the past two centuries: did the maskilim expect the German Jews of their time to understand the German language of their translations? Did they hope to utilize these translations to promote the learning of Hochdeutsch among their correligionists? Or did they simply wish to establish a model of the Jewish Bible in the German vernacular? In light of the present essay, it seems that some additional, related questions are warranted: Were Mendelssohn and his maskilic disciples influenced in their translation project not only by previous Jewish criti-

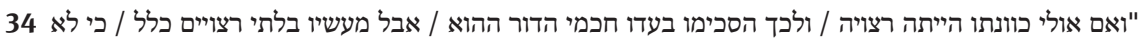

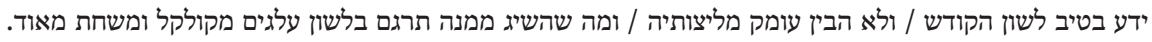

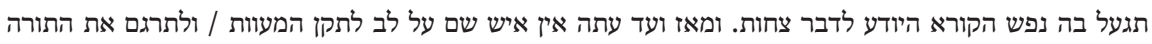

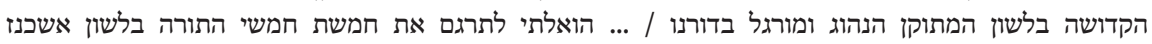

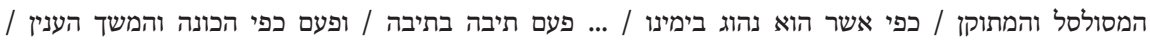
לחנכם [את הילדים] נכונת הכתוב ובמליצות המוג הלשון

Moses Mendelssohn, Or lintivah: ve-hu hakdama lahibur netivot hashalom ... (Berlin: [s.n.], 1783), n.p. English translation largely after Weinberg, "Language Questions," 222, 229. And see also the introduction by Mendelssohn and Solomon Dubno to Alim litrufah (1778): “[...] the books of the Bible have been translated into German by Yekutiel ben Isaac Blitz of Witmundt [...] but the translator, though motivated by good intentions, did a poor job, for not only was he ignorant in Hebrew, he did not know German either, and so "with stammering lips did he speak to his people'!” (English quote from Weinberg, "Language Questions,” 229).

35 On the maskilic discourse on Yiddish language and literature in late eighteenth-century Germany, including the maskilic German translations of biblical and other Jewish religious texts, such as the Passover Haggada or the Jewish prayer-book, see, especially, Shmeruk, Sifrut Yidish, Ch. 5; Römer, Tradition und Akkulturation, Ch.8. And see also Jeffrey A. Grossman, The Discourse on Yiddish in Germany: From the Enlightenment to the Second Empire (Rochester, NY: Camden House, 2000), Ch. 2. 
cism on the Yiddish biblical translations ${ }^{36}$ but also by early modern Christian discussions on the Yiddish Bible? Did the maskilim wish to present an alternative not only to the Protestant, German Bible, but also to the Yiddish versions produced by the Protestant missionaries? Did they internalize the centuries-long Christian criticism on the Yiddish Bible, sympathize with it, or respond to it in any way? Did they wish to prove the Christians wrong and show that Jews were, in fact, capable of producing a decent Ashkenazi Bible? To date, these remain open questions. Yet there is no doubt that the mere possibility of such an influence can shed new light on the extent and dynamics of Protestant-Jewish cultural transfer in the realm of the vernacular Bible, and the translation of religious texts, on the very threshold of modernity.

36 This internal Jewish criticism appears, for example, very clearly in the introduction of Yekutiel Blitz to his own Yiddish Bible from 1678, where he completely rejects the entire Ashkenazi tradition of biblical translations that preceded him, presenting his own translation as a new and improved Yiddish Bible in both language and style. Although present-day research confirms the novelty and modernizing tendencies of Blitz's translation, it was not perceived this way either by Christian scholars or by late eighteenth-century maskilim, as was demonstrated in this essay. 